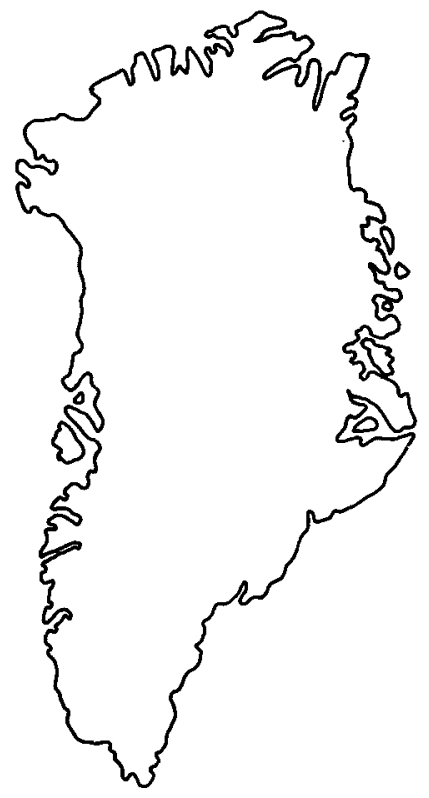

\title{
Archaeocyatha from the Lower Cambrian of Peary Land, central North Greenland
}

\author{
Françoise Debrenne and John S. Peel
}

\begin{abstract}
Archaeocyatha are reported from the Paralleldal Formation of the Brønlund Fjord Group, Peary Land, central North Greenland. Three new species are described and assigned to genera known from the upper part of the Lower Cambrian on the $\mathrm{Si}$ berian platform and in the Altai fold belt region. New taxa: $T e$ gerocyathella inesoni sp. nov., Tegerocyathus greenlandensis sp. nov., Archaeocyathus pearylandensis sp. nov.

F. D., Institut de Paléontologie, Centre National de la Recherche Scientifique, ER 154, 8 Rue de Buffon, 75005 Paris, France. J. S. P., Grønlands Geologiske Undersøgelse, Øster Voldgade 10, DK-1350 København K, Danmark.
\end{abstract}

The Archaeocyatha reported in this paper are the first recorded from the Cambrian of North Greenland, with the exception of a few crushed and silicified remains from the same general locality, which are too poor to merit description. The locality was discovered by Jon R. Ineson (University of Keele, now British Antarctic Survey) during summer field work in 1979, although the material described here results from collections made in the following summer. The locality lies on the north side of Sæterdal, near its junction with Paralleldal, southern Peary Land, central North Greenland (fig. 1) where cliffs of mainly Lower Cambrian carbonates rise above the drift filled valley floor.

All described specimens are from GGU sample 274908 collected from the Paralleldal Formation (fig. 2) of the Brønlund Fjord Group (Ineson \& Peel, in press), corresponding to the informally described formation 6 of Ineson \& Peel (1980) and Peel (1982). This formation attains its maximum observed thickness of $165 \mathrm{~m}$ in the Saterdal area and, at the collection locality, can be subdivided into two units. The lower, dark weathering unit consists of dark grey, silty, laminated dolomites which yield the crushed archaeocyathans noted above, associated with a rich silicified fauna of brachiopods (Kutorgina), molluscs (hyolithids, yochelcionellaceans), Chancelloria and trilobites (Kootenia, Olenellus) of Early Cambrian age. The dark dolomites are overlain by, and interdigitate to the south with, thick, massive, pale weathering crystalline dolomite. Finely crystalline mottled dolomite with archaeocyathans and rare trilobites occurs locally, but the dominant lithology is coarsely recrystallised, structureless, vuggy dolomite. Salterella maccullochi (Murchison, 1859) was described from the same unit by Peel \& Yochelson (1982) and, together with the archaeocyathans, confirms an Early Cambrian age.

The archaeocyathan assemblage from Peary Land contains Tegerocyathus (the most abundant), Archaeocyathus and Tergerocyathella. It is typical of the middle-late Toyonian stage 


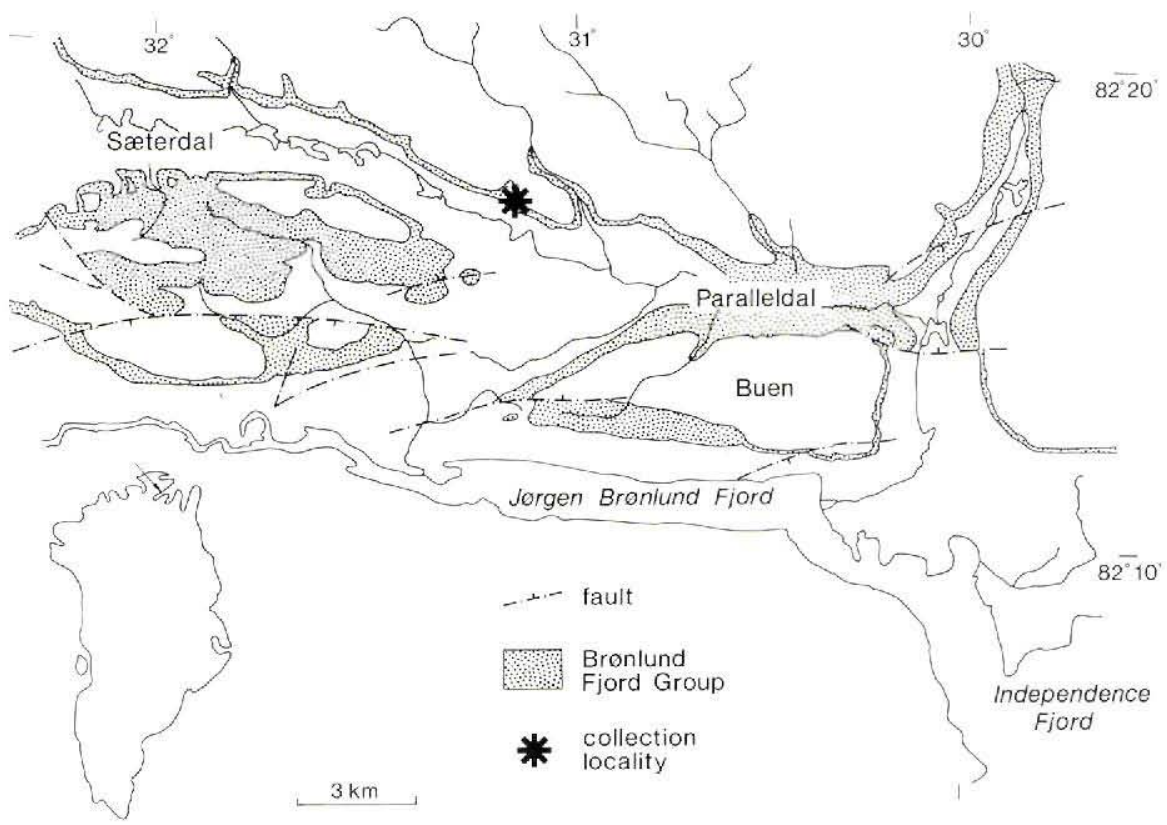

Fig. 1. The collection locality (star) for Archaeocyatha in southern Peary Land, central North Greenland.

(Elankian auctorum) of the late Early Cambrian. These genera are known in Siberia and the Altai Sayan folded region, in the Obrutchev and Elankian horizons. Archaeocyathan assemblages in Newfoundland and Labrador are of early Toyonian age; in the Appalachians and western Cordillera, archaeocyathan assemblages are even older (Botomian - early Toyonian). The Greenland fauna is thus the youngest known in the western world.

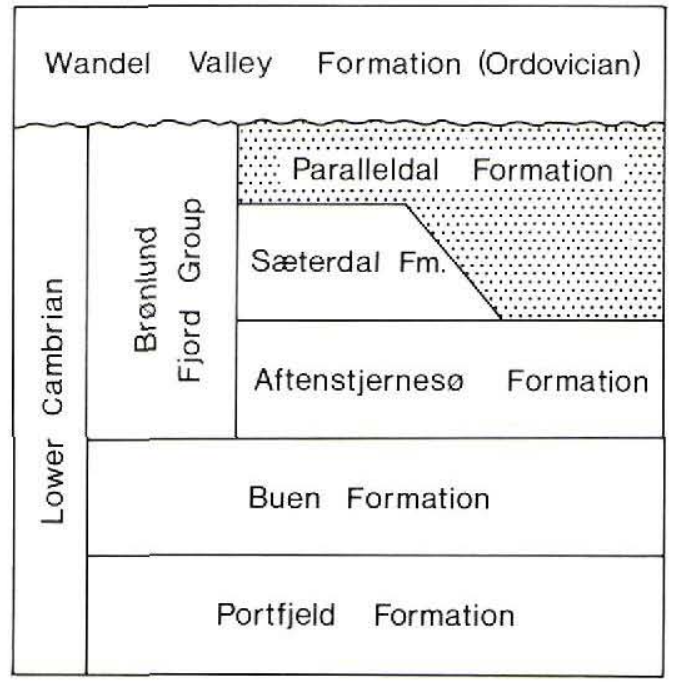

Fig. 2. Cambrian sequence in southern Peary Land, central North Greenland. Archaeocyathans were collected from the Paralleldal Formation (stippled). 
The Archaeocyatha had their greatest stratigraphic extent and widest diversity during the Botomian, with a stock of world-wide faunas. During the Toyonian (Elankian auctorum) there was a dramatic decrease in both the number of taxa and in the area of their distribution. Provincialism is the rule at species level, but correlations are possible with genera.

Deposition of material. Type and figured specimens are deposited in the type collection of the Geological Museum, Copenhagen (MGUH prefix). Other specimens are preserved by the Geological Survey of Greenland (GGU prefix); the form GGU 274908.32 means specimen number 32 from GGU sample 274908.

\section{Systematic palaeontology}

Class Regulares Vologdin, 1937

Family Tegerocyathidae Rozanov, 1973

Genus Tegerocyathella Konjushkov, 1967

Type species. Tegerocyathella borovikovi Konjushkov, 1967 by original designation (Konjushkov, 1967).

Diagnosis. Solitary cups, as expanded or stick-like cones. Double outer wall, the carcass often with funnel-shaped pores, covered at the outside by an attached microporous sheath. The radial septa are straight, non-porous to scarcely porous, with stirrup-pores. The inner wall is made of short straight canals linked to the septa by large stirrup-pores: there is one stirrup-pore in front of each septa and an additional row of pores in the middle of each interseptum.

Discussion. Oblique sections give the impression of a more complicated inner wall; it is the result of the combination of stirrup-pores and short canals.

Comparisons. Tegerocyathella differs from Tegerocyathus by the shortness of the inner wall pore-tubes and the absence of lateral communications between them.

Geographic and stratigraphic distribution. Altai Sajan, Siberian Platform, Obrutchev and Elansk horizons. Greenland, upper part of the Lower Cambrian.

Tegerocyathella inesoni sp. nov.

Figs 3, 4, 5A-C

Derivation of name. Dedicated to Jon R. Ineson, who discovered the locality.

Holotype. MGUH 17.077 from GGU 274908.13, Paralleldal Formation, Peary Land.

Other figured material. MGUH 17.078 from GGU 274908.52.

Material studied. 9 specimens from GGU 274908. 


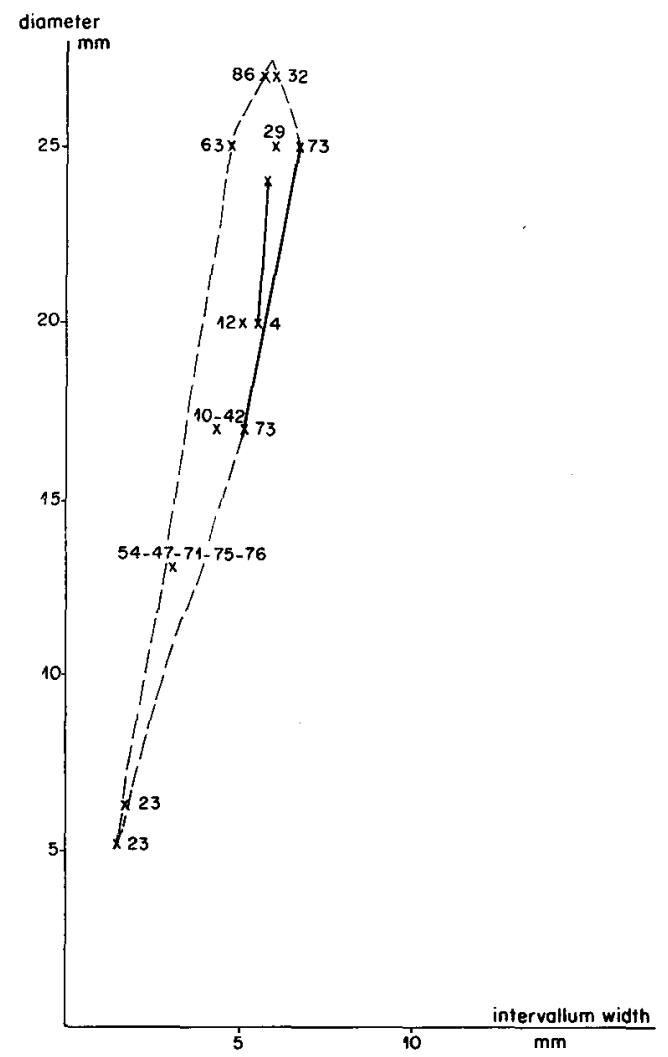

Fig. 3. Tegerocyathella inesoni sp. nov., intervallum coefficients (ratio between the width of the intervallum and the diameter of the cup). Numbers are specimen numbers within GGU sample 274908 , e.g. ' 23 ' is specimen number GGU 274908.23.

Description. Cyclindro-conical cups up to a diameter of $16 \mathrm{~mm}$ for a height of about $50 \mathrm{~mm}$. The intervallum, relatively large $(2.5 \mathrm{~mm})$, giving an intervallum coefficient varying from 0.15 to 0.25 . The septa, $0.70 \mathrm{~mm}$ apart, delimit interseptal chambers (loculi), the ratio of the sides of which is 1:3. Parietal coefficient is nearly constant and equal to 3 to 3.5 (fig. 3 ).

The preservation of the skeleton is coarse. The very delicate structures are generally not preserved, only traces can be detected. For instance, the double structure of the outer wall may be inferred from the funnel shape of the carcass and its coating by a thin external envelope, the porosity of which is not observed (fig. $5 \mathrm{C}$ ). The thickness of the wall is about 0.15 $\mathrm{mm}$, with interpore lintels of 0.10 . The septa are nearly non-porous except for distant pores and stirrup-pores on both walls. The thickness of septa is $0.05 \mathrm{~mm}$. The inner wall is made of a double system: large stirrup-pores in front of each septa and an additional row of horizontal pore-tubes of the same diameter between two adjacent septa. The thickness of the wall may reach $0.4 \mathrm{~mm}$, but the average is $0.3 \mathrm{~mm}$. The diameter of the pores is 0.20 to 0.25 $\mathrm{mm}$ and the lintels 0.18 to $0.20 \mathrm{~mm}$. Except for the stirrup-pores, there is no lateral communication through the wall of the pore-tubes.

Discussion. There is no doubt that this species belongs to the genus Tegerocyathella; three species are presently known: T. borovikovi Konjushkov, 1967, T. diploperforata (Vologdin, 


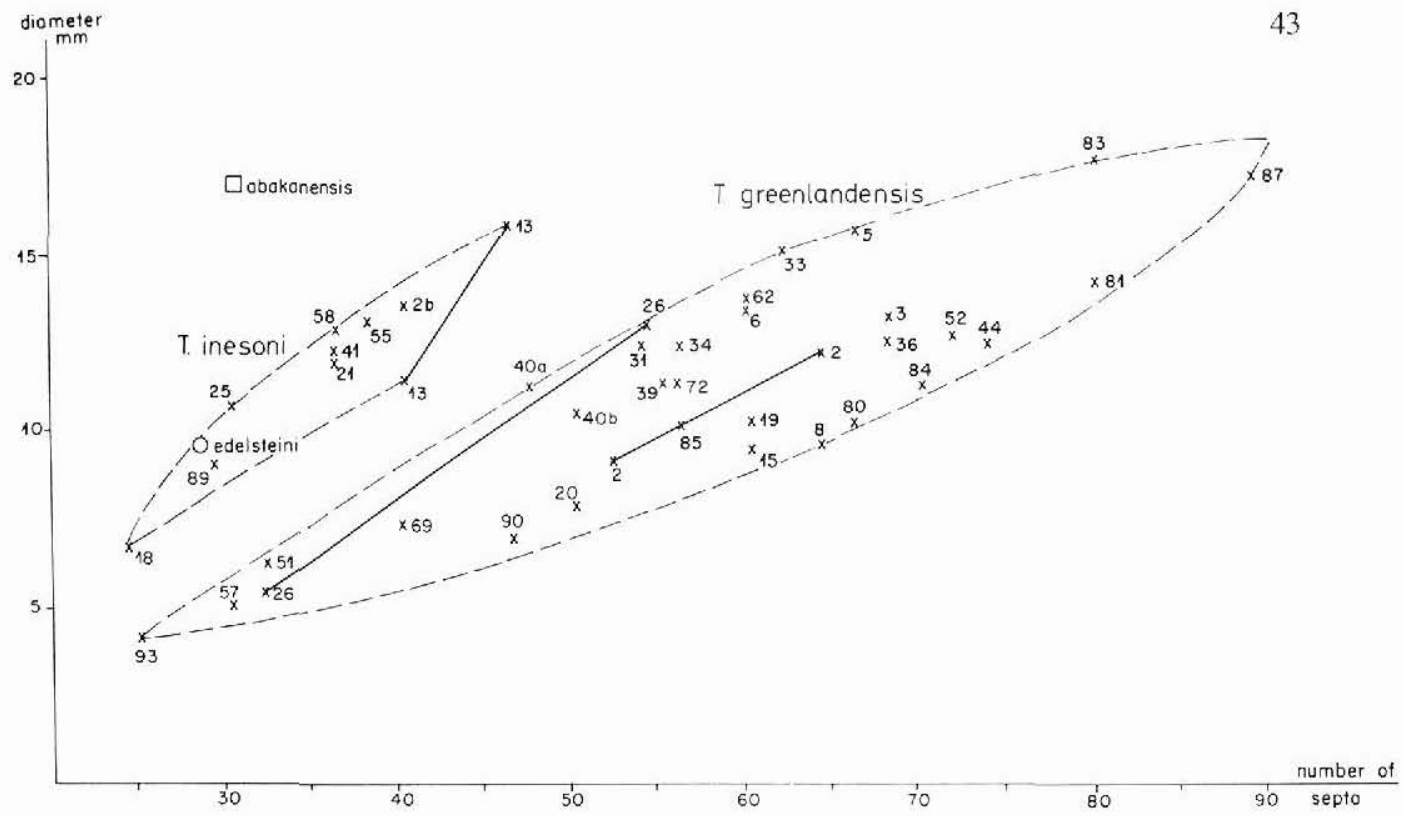

Fig. 4. Tegerocyathus greenlandensis sp. nov., parietal coefficients (ratio between the number of septa and the diameter) compared with Tegerocyathella inesoni sp. nov., Tegerocyathus abakanensis (Vologdin, 1940) and Tegerocyathus edelsteini (Vologdin, 1940). Numbers are specimen numbers within GGU sample 274908 , e.g. '93' is specimen number GGU 274908.93.
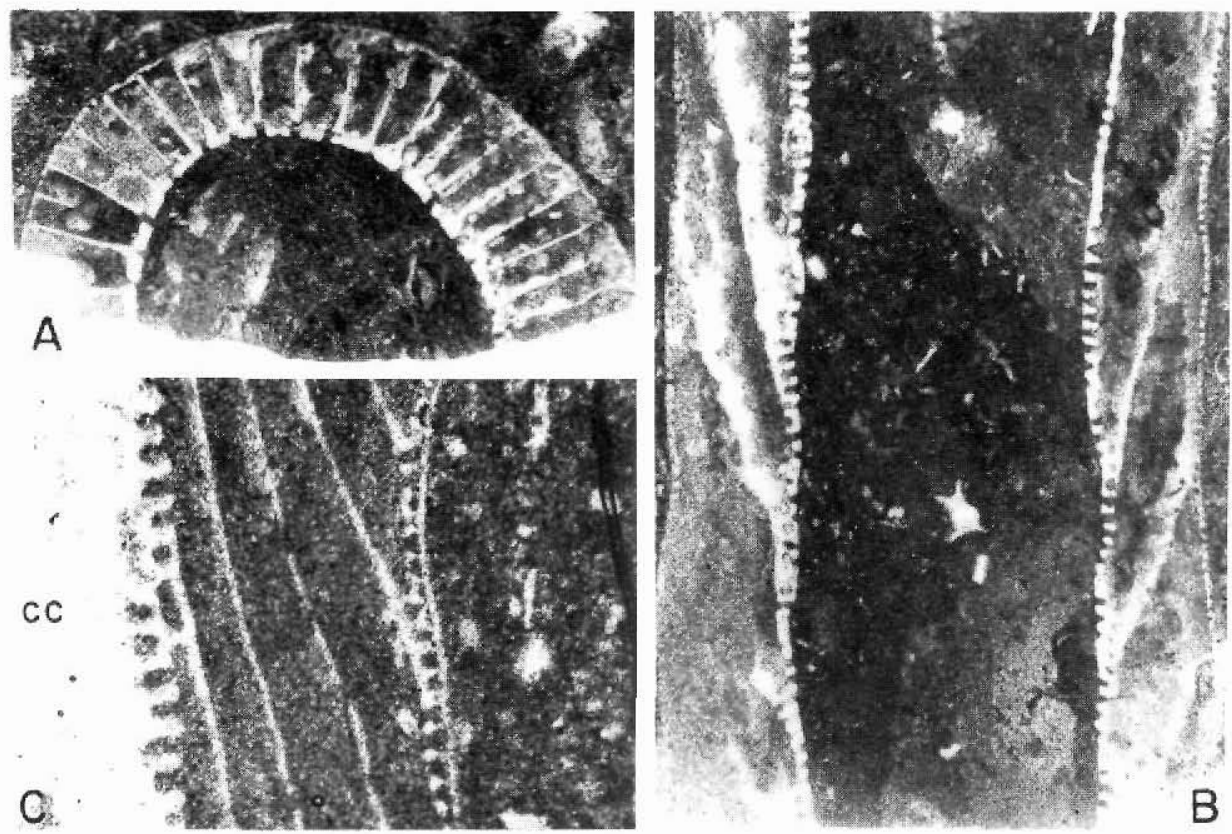

Fig. 5. Tegerocyathella inesoni sp. nov. A, transverse section of holotype, MGUH 17.077A from GGU $274908.13, \times 4$. B, longitudinal section of holotype, MGUH 17.077B from GGU 274908.13, $\times 10$. C, double outer wall of paratype, MGUH 17.078 from GGU 274908.52, × 10. cc, central cavity. 
1940), T. expansiva Kashina, 1979. They all differ from $T$. inesoni by their parietal coefficient, their intervallum coefficient, and their shape and size.

\section{Genus Tegerocyathus Krasnopeeva, 1955}

Type species. Not designated in the first publication, subsequent designation by Krasnopeeva $(1955, \mathrm{p}$. 90) as Ethmophyllum abakanensis Vologdin, 1940. Zhuravleva (1960, p. 180) and Zhuravleva et al. (1960, p. 116) made another choice, Ethmophyllum edelsteini Vologdin, 1940 which was followed by Hill (1972) in the Treatise on Invertebrate Paleontology.

Diagnosis. Solitary, rarely colonial cups. Double outer wall with a carcass of funnel-pores screened by an attached microporous sheath. The septa are sparsely porous to porous; they may bifurcate. Inner wall with intercommunicating pore-tubes and stirrup-pores with septa.

Discussion. Doubt has arisen concerning the type species of this genus. Most of the Russian authors and Hill (1965) considered Ethmophyllum abakanensis as the type species. It is important to note that in the first publication of the name Tegerocyathus, Krasnopeeva (1953) included within the genus two new species, without description or designation of type, only known through ink-drawings. In 1955 she designated E. abakanensis Vologdin, 1940 as the type and quoted $T$. erbiensis $\mathrm{n}$. sp. as a member of the genus, together with altaicus, diploperforatum and one of the 1953 species tannuola; the other 1953 species was not quoted here. Zhuravleva et al. (1960) included abakanensis and edelsteini within Tegerocyathus, and abakanensis was confirmed as the type species. No other species are quoted. Zhuravleva (1960) for the first time coined Ethmophyllum edelsteini as the type species, but incorrectly quoted Krasnopeeva (1953): the cited page is not the page where Tegerocyathus appears for the first time (p. 55 and not p. 36) and E. edelsteini was not included in 1953 (p. 36) by Krasnopeeva in her first article, as assumed by Zhuravleva.

More confusing is the fact that Zhuravleva (1960) transferred the two first quoted species, T. tannuola and T. potaechinis, into her new genus Porocyathus, instead of selecting one of them for the type of Tegerocyathus, as should have been done according to the recommendations of the International Code of Zoological Nomenclature, if the 1953 publication is considered as valid concerning the establishment of the genus.

Surprisingly, Hill in the Treatise (1972, p. E74) followed Zhuravleva in her choice, though she had concluded differently in 1965 (p. 84), considering abakanensis as the type.

The International Code of Zoological Nomenclature (1964, p. 69, art. 69a) states: "If an author ... did not designate or indicate its type species any zoologist may subsequently designate as the type species one of the originally included nominal species, or if there were no original nominal species, one of those first subsequently referred to the genus." In the present case, one can argue that no species were nominated in the first publication as Krasnopeeva (1953) presented only figures without any reference in the text. So we have to take into account the first revision (Krasnopeeva, 1955, p. 90) in selecting a type species, i.e. $E$. abakanensis Vologdin, 1940 should be type species. The problem is made even more complicated as Rozanov (in Egorova et al., 1976, p. 51) saw no possibility of distinguishing $E$. abakanensis from E. edelsteini, though Kashina (in Osadchaya et al., 1979) coined a new genus including edelsteini but not abakanensis (genus Alexandricyathus Kashina, 1979). 


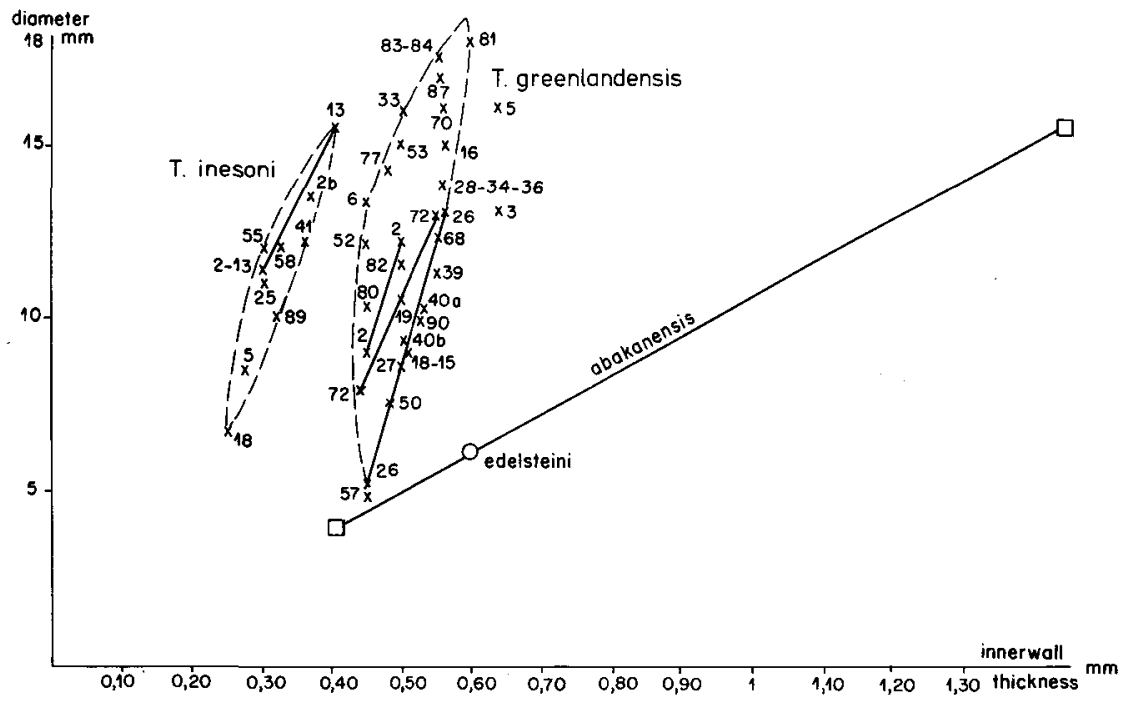

Fig. 6. Relationship between the thickness of the inner wall and the diameter in Tegerocyathus greenlandensis sp. nov., compared with T. edelsteini (Vologdin, 1940) and Tegerocyathella inesoni. Numbers are specimen numbers within GGU sample 274908, e.g. '93' is specimen number GGU 274908.93.

All things considered, it is proposed to confirm E. abakanensis as the type species of Tegerocyathus with 1955 as the date of authorship and Alexandricyathus as a junior synonym of Tegerocyathus (Debrenne \& Rozanov, 1983).

As stated above, Rozanov suggested that edelsteini (with sparsely porous septa) could not be separated from abakanensis (with more porous septa). In the material presently studied, one sample shows porous septa, the other nearly imperforate septa, with all other characters being equal. It is for this reason that porosity of septa is not considered as a significant character.

Geographic and stratigraphic distribution. Western Siberia, Obrutchev horizon, Altai Sajan, Mongolia, Tuva, Far East, Sanachtygkol and Obrutchev horizons or equivalent. Siberian Platform, Elansk horizon. Greenland, upper part of the Lower Cambrian.

Tegerocyathus greenlandensis sp. nov.

Figs 4, 6, 7A-G

Derivation of name. From Greenland.

Holotype. MGUH 17.079 from GGU 274908.19. Paralleldal Formation, Peary Land.

Other figured material. MGUH 17.080 - MGUH 17.084.

Material studied. 38 specimens. 
Description. Cylindro-conical cups, solitary or rarely colonial. The outer shape is often affected by smooth undulations of both walls. The cups are nearly cylindrical up to a diameter of $11 \mathrm{~mm}$, then begin to expand into a more opened cone, the intervallum remaining nearly constant in size. Two specimens show the beginning of the formation of a colonial form, but without accomplishing it (fig. 7C). All the others are solitary cups, up to $18 \mathrm{~mm}$ in diameter for a height of more than $50 \mathrm{~mm}$. The outer wall is double, as in the form described above: a carcass with funnel-shaped pores screened by an attached microporous sheath. Most of the time the secondary envelope is not well seen in the specimens, the only remaining structure being an external coating, but in some cases it is possible to observe the whole structure (fig. 7B). There are 2 to 4 carcass-pores per intersept. The pores of the main carcass vary from 0.07 to $0.15 \mathrm{~mm}$ in diameter, the interpore lintels from 0.10 to $0.15 \mathrm{~mm}$. The total thickness is 0.10 to $0.15 \mathrm{~mm}$. The microporous sheath has micropores of $0.03 \mathrm{~mm}$ in diameter, and lintels of $0.03 \mathrm{~mm}$. The intervallum is rather constant, 2 to $2.25 \mathrm{~mm}$ in width, crossed by radial septa, 0.40 to $0.50 \mathrm{~mm}$ apart; the ratio of the loculi sides is $1: 4$ to $1: 5$; the intervallum coefficient varies from 0.15 to 0.25 .

The number of septa increases with the diameter (fig. 4), within certain limits. The radial coefficient varies from 4.5 to 6 , the most frequent being 5.5. The thickness of septa is 0.03 $\mathrm{mm}$ to $0.05 \mathrm{~mm}$. Except for one specimen, septal pores are absent or restricted to one row of pores against the walls. The inner wall is made of a system of horizontal pore-tubes, one in front of each septa, with which they are combined by means of stirrup-pores, plus another pore-tube in the middle of each interseptum; lateral sides of tubes are perforated by one pore (fig. 7F); in some cases, neighbouring pore-tubes of the same horizontal line intercommunicate to form a horizontal pore-chamber (fig. 7E). The thickness of the wall varies with the diameter but large widths are not attained. Only one row of lateral pores is known. The aperture of the pores is $0.18 \mathrm{~mm}$ to $0.26 \mathrm{~mm}$ in diameter, the wall of the tube $0.10 \mathrm{~mm}$ to $0.18 \mathrm{~mm}$ in thickness. The total width of the inner wall varies from $0.40 \mathrm{~mm}$ to $0.60 \mathrm{~mm}$. In addition to variation associated with growth, some samples show a remarkable thickness of the inner wall and are situated in the graph (fig. 7D) apart from the main population. It is noticeable that one of these specimens is a colonial form. They are considered, all other coefficients being equal, as intra-specific variations.

Discussion. The present species differs from the other species of the genus by its parietal coefficient and by the relative thickness of the inner wall. In other species the inner wall width increases rapidly with the diameter and reaches a great thickness in adult cups, each lateral pore-tube bearing more than one lateral row of pores. This is well seen in fig. 6 , where the evolution of inner wall thickness is related to the diameter.

Fig. 7. Tegerocyathus greenlandensis sp. nov. A, transverse section of the holotype, MGUH 17.079A from GGU $274908.19, \times 5$. B, tangential section of the double outer wall of the holotype, MGUH 17.079B from GGU 274908.19, $\times 10$. C, beginning of the formation of a colonial form, MGUH 17.080 from GGU 274908.85, $\times 5 . \mathrm{D}$, remarkable thickness of the inner wall pore-tubes, paratype, MGUH 17.081 from GGU 274908.5, $\times$ 4. E, horizontal pore-chambers in the inner wall, paratype, MGUH 17.082 from GGU $274908.70, \times 10 . \mathrm{F}$, lateral perforation of the inner wall pore-tubes, paratype, MGUH 17.083 from GGU 274908.44, × 10. G, septal pores from paratype, MGUH 17.084 from GGU $274908.28, \times 10 . c c$, central cavity. 

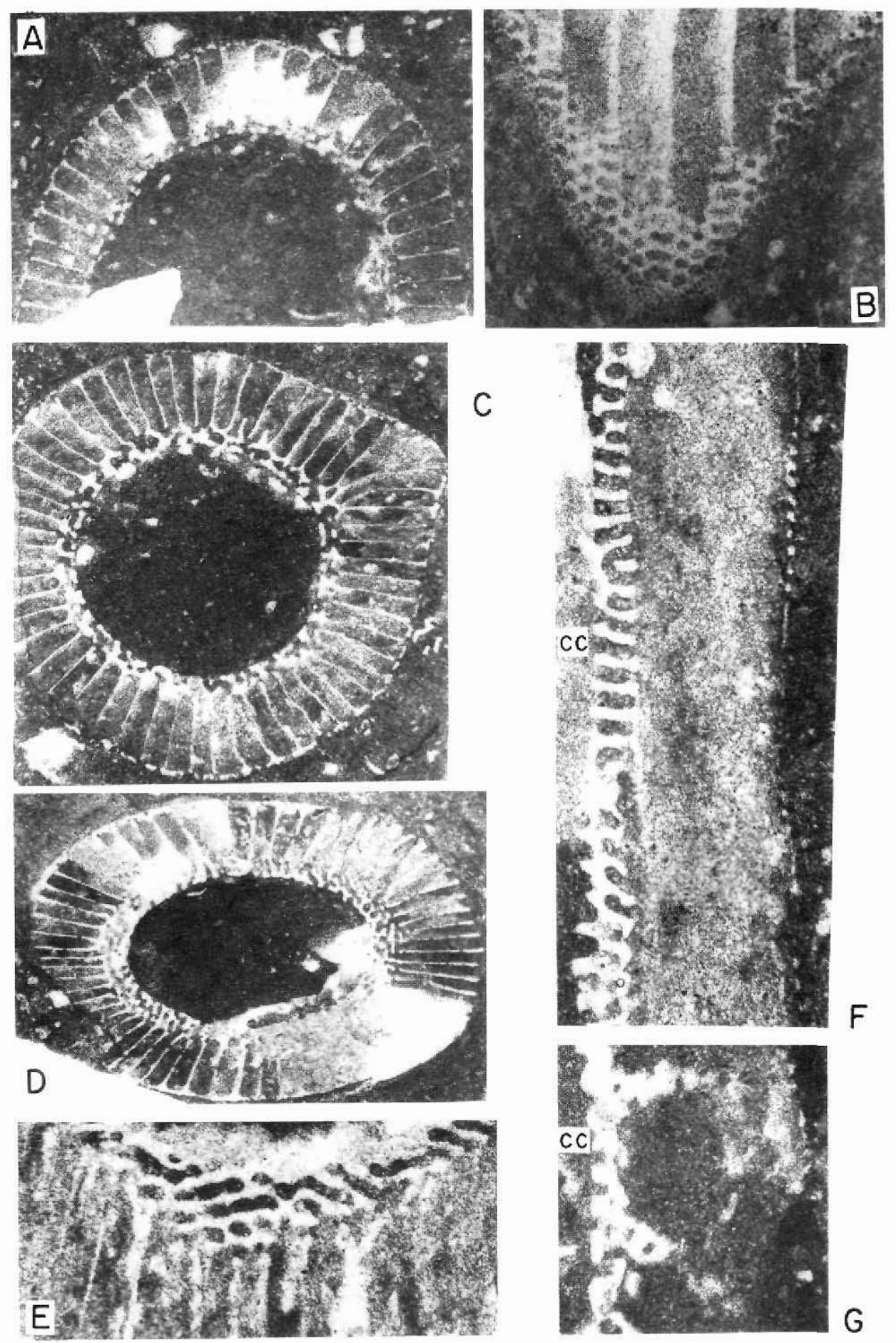
Type species. A. atlanticus Billings, 1861, by subsequent designation of Walcott (1886).

Diagnosis. Conical cups with few smooth transverse constrictions. Outer wall with fairly regular small pores, intervallum made of pseudosepta (or taeniae) undulating, sometimes bifurcating; presence of synapticulae and dissepiments. Inner wall with one pore-tube per intertaenial space, oblique upward. Secondary lamination often present and with an important development.

Discussion. All variations are possible, in terms of the number of synapticulae, the development of dissepimental tissue and of secondary layers of skeleton.

Geographic and stratigraphic distribution. Labrador, western Cordillera (North America), Antarctica, Siberian Platform, Far East. Altai Sajan, Mongolia, Tuva, China, Spain. Sanachtygkol and Obrutchev horizons and their equivalent. Greenland, upper part of the Lower Cambrian.

Archaeocyathus pearylandensis sp. nov.

Fig. $8 \mathrm{~A}-\mathrm{C}$

Derivation of name. From Peary Land, the type locality.

Holotype. MGUH 17.085 from GGU 274908.32, Paralleldal Formation, Peary Land.

Other figured material. MGUH 17.086 from GGU 274908.63.

Material studied. 16 specimens from GGU 274908.

Description. Large fragments of cylindrical cups with transverse smooth constrictions and bulges. The type specimen has a diameter of $27 \mathrm{~mm}$, a fairly large central cavity $(14 \mathrm{~mm})$ and an intervallum varying from 5.9 to $7.2 \mathrm{~mm}$, depending upon whether measurement is made in a bulge or in a constriction. The corresponding intervallum coefficients are 0.21 to 0.26 , these coefficients being nearly constant throughout the population considered (fig. 8A). The height of cups may reach $90 \mathrm{~mm}$ for a diameter of $25 \mathrm{~mm}$.

The outer wall, when preserved, is perforated by small pores, 2-3 per intertaenial space, with a diameter of $0.07 \mathrm{~mm}$, an interpore lintel of $0.10 \mathrm{~mm}$ and a thickness of $0.10 \mathrm{~mm}$.

The intervallum is crossed by more or less radial undulating pseudosepta, perforated by regular pores (diameter $0.30 \mathrm{~mm}$, interpores $0.20 \mathrm{~mm}$ ) set in vertical oblique rows. The pseudosepta are 0.50 to $0.60 \mathrm{~mm}$ apart. They are connected by synapticulae, which join the opposing crests of the waving septa (fig. 8C).

Fig. 8. Archaeocyathus pearylandensis sp. nov. A, transverse section of holotype, MGUH 17.085A from GGU 274908.32, × 4. B, longitudinal section of holotype, MGUH 17.085B from GGU 274908.32, $\times 4$. C, detail of taeniae, paratype, MGUH 17.086 from GGU 274908.63, $\times 10$. cc, central cavity. 


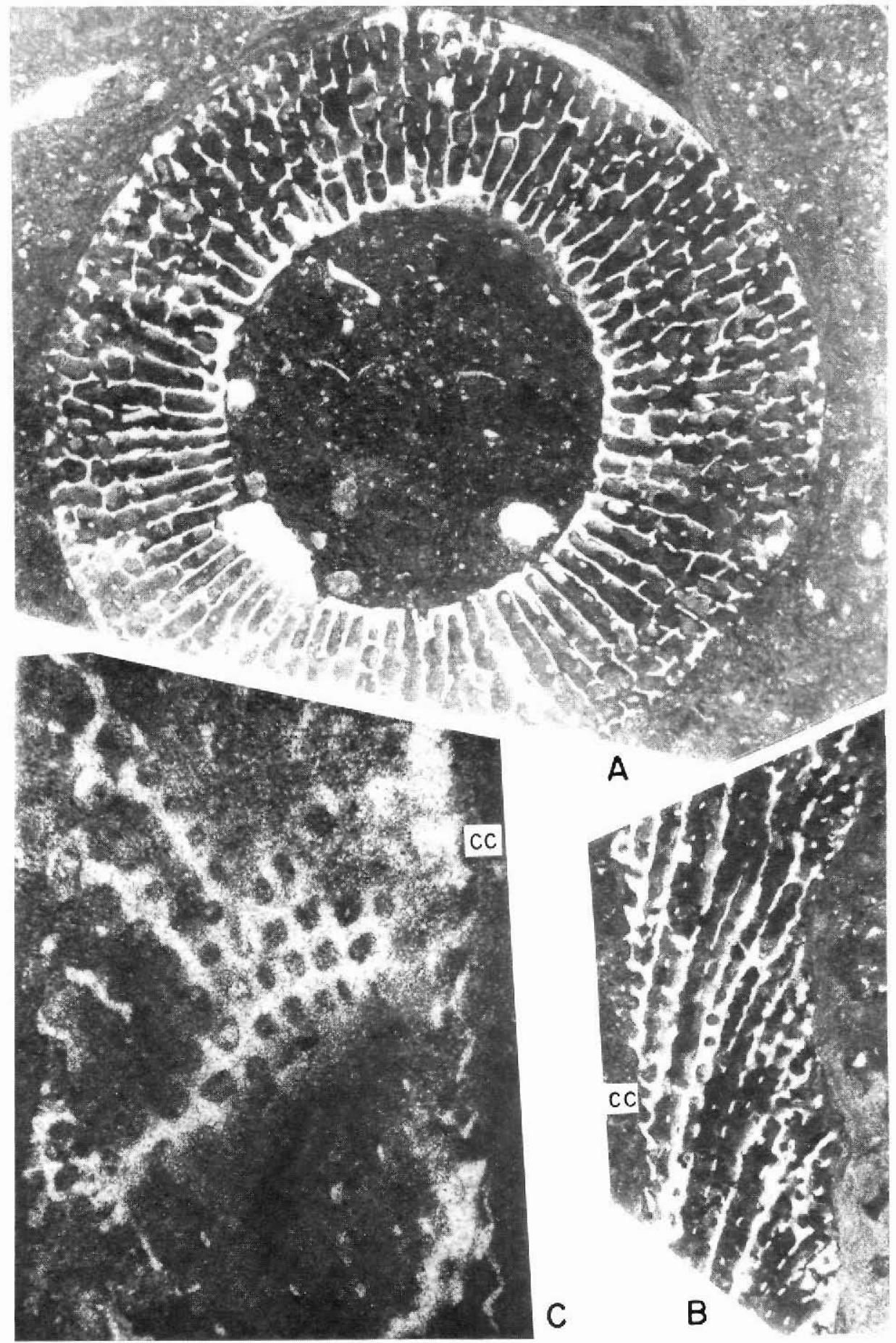


Neither dissepiments nor stereoplasma are present. The inner wall has one vertical row of short pore-tubes, directed obliquely upward and forming a sharp angle with the intervallum (fig. 8B). The opening of the pore-tubes has a diameter of $0.45 \mathrm{~mm}$; the tube has a thickness of $0.20 \mathrm{~mm}$, a total length of $0.90 \mathrm{~mm}$, and the width of the wall is $0.4 \mathrm{~mm}$.

Discussion. The absence of dissepiments and stereoplasma is known from several other species, mainly from the Elankian stages (altaicus, subradiatus, seliverstovae). They differ from the present form by different values of coefficients (narrower or larger central cavity) and/or different distribution of septa (more numerous in altaicus) for the same intervallum coefficient, for instance.

\section{References}

Debrenne, F. \& Rozanov, A. 1983: Paleogeographic and stratigraphic distribution of Regular Archaeocyatha (Lower Cambrian fossils). Géobios 16, 6, 727-736.

Egorova, L. I., Chabanov, Yu. Ya., Rozanov, A. Yu., Savitsky, V. E., Chernysheva, N. E. \& Chichkin, V. V. 1976: Elanskii i Kuonamskii Fatsiosrtratotypy nizhnei granitsy srednego kembriya Sibiri. M. 'Nedra' 1976, Trudy SNIGGIMS 211, 150 pp.

Hill, D. 1965: Archaeocyatha from Antarctica and a review of the phylum. Pub. Trans-Antarctic Expedit. Committee 10, 3, $150 \mathrm{pp}$.

Hill, D. 1972: Archaeocyatha. In Moore, R. C. (edit.) Treatise on invertebrate paleontology E, (2nd edit.). Lawrence: Geol. Soc. Am. and Kansas U.P., 158 pp.

Ineson, J. R. \& Peel, J. S. 1980: Cambrian stratigraphy in Peary Land, eastern North Greenland. Rapp. Gronlands geol. Unders. 99, 33-42.

Ineson, J. R. \& Peel, J. S. in press: Cambrian shelf stratigraphy of the Peary Land region, central North Greenland. Bull. Grønlands geol. Unders.

Konjushkov, K. N. 1967: Novye dannye po arkheociatam gor Agyrek severo-vostochnogo Kazakhstana. Biostratigraficheskij sbornik 3, Trudy VSEGEI 129, 104-113.

Krasnopeeva, P. S. 1953: Osobennosti kameshkovskogo Kompleksa arkheotsiat v fatsii effusivno-osadochnykh otlozheniy na primere arkheotsiat zapadnoi chasti Tuvy. Trudy Tomsk Gosud. Univ., ser. geol. 124, 51-62.

Krasnopeeva, P. S. 1955: Tip Archaeocyathi, Arkheotsiati. In Khalfina, L. L. (edit.) Atlas rukovodyashchikh form iskopaemykh fauny i flory Zapadnoy Sibiri 1, 74-102. Moskva: Gosgeoltekhizdat.

Osadchaya, D. V., Kashina, L. N., Zhuravleva, I. T. \& Borodina, N. P. 1979: Stratigrafiya i Archeotsiaty nizhnego Kembryia. Altae Sayanskoy oblasti. Moskva: Nauka, 216 pp.

Peel, J. S. 1982: The Lower Palaeozoic of Greenland. In Embry, A. F. \& Balkwill, H. R. (edit.) Arctic geology and geophysics. Mem. Can. Soc. Petrol. Geol. 8, 309-330.

Peel, J. S. \& Yochelson, E. L. 1982: A review of Salterella (Phylum Agmata) from the Lower Cambrian in Greenland and Mexico. Rapp. Grønlands geol. Unders. 108, 31-39.

Walcott, C. D. 1886: Second contribution to the studies on the Cambrian faunas of North America. Bull. U.S. Geol. Surv. 30, 369 pp.

Zhuravleva, I. T. 1960: Arkheotsiaty Sibirskoy platformy. Moskva: Akad. Nauk SSSR, 344 pp.

Zhuravleva, I. T., Krasnopeeva, P. S. \& Chernysheva, S. V. 1960: Tip Archaeocyathi. Arkheotsiati. In Khalfina, L. L. (edit.) Biostratigrafiya paleozoya Sayano-Altayskoy gornoy oblasti. Trudy SNIGGIMS 19, 97-140. 